\title{
Fatty Acid Transfer From Sow to Piglet Differs for Different Polyunsaturated Fatty Acids (PUFA)
}

\author{
S. SAMPELS ${ }^{1}$, J. PICKOVA ${ }^{1}$, A. HÖGBERG ${ }^{1}$, M. NEIL ${ }^{2}$ \\ ${ }^{1}$ Department of Food Science, Swedish University of Agricultural Sciences, Uppsala, Sweden, \\ ${ }^{2}$ Department of Animal Nutrition and Management, Swedish University of Agricultural Sciences \\ Funbo-Lövsta, Uppsala, Sweden
}

Received August 20, 2010

Accepted September 21, 2010

On-line October 15, 2010

\begin{abstract}
Summary
Polyunsaturated fatty acids (PUFA) are essential for the development of the nervous system in animals. It is known that pigs are good models for human in many aspects. The aim of the study was to investigate how fat content and FA composition in sows' diet influence FA composition in brain of newborn and in liver and brain of one-day-old piglets, respectively. High fat (6 $\%$ feeds were designed with regard to saturated or polyunsaturated fat content and $n-6 / n-3$ ratio by adding either oats rich in linoleic acid (LA) or linseed oil rich in a-linolenic acid (ALA). The ratio $n-6 / n-3$ PUFA was 11 in all three diets (the low fat (3\%), high fat saturated and high fat oats diet), while the ratio in the linseed oil diet was 2 . Increased proportion of ALA in the diet increased ALA and eicosapentaenoic acid (EPA) in piglets' neutral and polar liver lipids and the long chain PUFA, EPA, docosapentaenoic and docosahexaenoic acid in piglet brain. The results suggest that transport of n-3 PUFA from sow to piglet was higher via milk than via bloodstream in the uterus and that increased content of ALA in sows' feed led to an increased accumulation of n-3 FA in piglets' liver and brain.
\end{abstract}

\section{Key words}

$\mathrm{DPA} \bullet \mathrm{DHA} \bullet$ Fat content $\bullet$ Linseed oil $\bullet$ Metabolism

\section{Corresponding author}

Sabine Sampels, Department of Food Science, Swedish University of Agricultural Sciences, Uppsala, Sweden. Fax: 004618672995. E-mail: Sabine.Sampels@Imv.slu.se

\section{Introduction}

So far sow diets have been composed with regard to protein, vitamins, minerals and energy demands, while the needs for n-3 essential fatty acids (FA) in animal nutrition have not been fully recognised. Today, the most commonly used raw material in pig diets in Sweden are cereals, which contain in the lipid fraction mostly monounsaturated FA (MUFA) and n-6 polyunsaturated FA (PUFA). Few attempts have been made to design a feed with a lipid composition that fulfils sows' physiological needs for PUFA including a wellbalanced ratio of n-6/n-3 FA. The most obvious goal has often been a cheap and not easily oxidised lipid source resulting in a high dietary ratio of $n-6 / n-3$ FA, often exceeding 10:1, whereas for humans a ratio of 1-4 has been recommended (Simopoulos 2002).

It is well established that the maintenance of optimal pre- and postnatal growth and development requires n-3 PUFA (Innis 1991, Innis et al. 1999). The nervous system of newborns has a large demand for these PUFA. The retina and brain of mammals is in general very rich in docosahexaenoic acid, 22:6n-3 (DHA) and arachidonic acid, 20:4n-6 (AA) (Lauritzen et al. 2001). Passingham (1985) has shown that in both pigs and humans the development of the brain occurs mainly in the last period of pregnancy and in early postnatal life. The need of DHA or its precursors from external sources in piglet retina and brain has been demonstrated by Leskanich (1999). Rooke et al. (2001) showed that supplementation of salmon oil in sows diet increased piglet survival during lactation despite a lower birth weight of piglets.

Powles et al. (1994) found that diets with a higher ratio of unsaturated FA to saturated FA gave 
increased values of digestibility of dietary fat, which is important as the total lipid content of piglets' carcass is very low and they need to take up fat via milk.

Finally, a high dietary fat content for sows might be advantageous as milk has been shown to have increased fat content if sows have increased fat intake (reviewed by Farnworth and Kramer 1987)) which is an additional benefit to insure sufficient energy intake of the piglets.

Dietary FA composition direct as well as Sows diet via milk influenced FA composition of various tissues in piglets (Amusquivar et al. 2008, Lauridsen and Jensen 2007, Missotten et al. 2008, Panella-Riera et al. 2007).

In 1981, the Agricultural Research Council, ARC recommended essential FA to be $1.5 \%$ of the dietary dry matter for pigs up to $30 \mathrm{~kg}$, and $0.7 \%$ from 30 to $90 \mathrm{~kg}$ of weight (ARC, 1981). Cunnane (1984) identified both linoleic acid 18:2 n-6 (LA) and AA as essential FA that should be supplied in pig diets. The National Research Council (NCR, 1998) suggested that the dietary requirement for essential FA for all classes of pigs would be met from a dietary level of $0.1 \%$ LA per $\mathrm{kg}$ diet. For reproductive functions, pig diets should include $0.5 \% \mathrm{AA}$ and $0.7 \% \mathrm{LA}$ per $\mathrm{kg}$ diet, according to Close and Cole (2000). In addition Blanaru et al. (2004) showed positive effects on bone mass of piglets. However, no recommendation for n-3 FA is given in this literature.

\section{Materials and Methods}

\section{Animals and housing}

In the experiment 39 litters from multiparous Swedish Yorkshire sows were used, from weaning of the previous litter until weaning of the experimental litter. During the service and pregnancy periods sows were group housed (maximum 16 sows per group) in large pens $\left(52 \mathrm{~m}^{2}\right)$ on deep straw bedding and with individual feeding stalls. One week before expected farrowing sows were moved to individual farrowing pens $\left(8.5 \mathrm{~m}^{2}\right)$, with heated concrete floors slatted $\left(2.5 \mathrm{~m}^{2}\right)$ over the dunging area.

Sows were fed the experimental diets twice daily from the afternoon of the day of weaning the previous litter (the litter preceding the experimental litter). From weaning until service the daily allowance was $4 \mathrm{~kg}$ (approximately $50 \mathrm{MJ} \mathrm{ME}$ ). During pregnancy sows were fed according to live weight and ultrasonic backfat at service. The daily allowance was $28 \mathrm{MJ}$ ME for sows with live weights less than $140 \mathrm{~kg}, 33 \mathrm{MJ}$ ME for sows weighing between 140 and $180 \mathrm{~kg}, 35 \mathrm{MJ}$ ME for sows weighing between $180-220 \mathrm{~kg}$, and $37 \mathrm{MJ}$ ME for sows heavier than $200 \mathrm{~kg}$. Sows with back fat thinner than $14 \mathrm{~mm}$ were fed $5 \mathrm{MJ}$ ME extra per day during week 4-13 of pregnancy.

Backfat was measured ultrasonically (Krautkrämer GmbH and Co., Hürth, Germany), approximately $8 \mathrm{~cm}$ from the midline on both sides, at the level of the last rib, and the mean was recorded.

From the day after farrowing, the allowance was increased by $1 \mathrm{~kg}$ daily until reaching the full allowance of $101 \mathrm{MJ} \mathrm{ME} \pm$ 7.6 MJ ME per piglet deviating from litter size 10 (Simonsson 1994). The average feed intake within feeding groups was similar.

Dietary treatments consisted of four cereal based diets (with soy as protein enhancement) with a conventional low fat (LF) (3\%) sow diet and three high fat $(6 \%)$ diets; High fat saturated (HFS), high fat oats (HFO) and high fat linseed (HFL). Composition and analysed nutrient content are presented in Table 1a. In the diets HFO and HFL, high-fat oats was included (var. Matilda. Svalöf Weibull AB, Svalöf, Sweden), $40 \%$ and $20 \%$, respectively. Variety Matilda contains about $10 \%$ fat of total dry matter, compared to ca $6 \%$ in normal oats. HFS and HFO feed contained in addition commercial fat blends of vegetable origin (Ako feed cattle high (40-45\% saturated FA (SFA)) and Ako Feed standard (17\% LA) (Karlshamns Group, Karlshamn, Sweden) respectively). Feed HFL, included linseed oil (Alternativ Förädling AB, Glanshammar, Sweden), which was added by hand at feeding time, as a top-dress at a rate of $1 \%$ by weight. The diets were calculated to meet or exceed nutrient requirements according to Swedish recommendations of breeding sows (Simonsson 1994). The added fat blends, with distinct saturation profiles, consisted mainly of free FA, which were chosen as a source of medium- or longchain (LC) FA, respectively. Feed mixtures were offered as crumbles. Sows had free access to water.

Immediately following birth, one piglet per litter, preferably the third born, was rendered unconscious by $\mathrm{CO}_{2}$, bled to death, and dissected. For practical reasons we found the $3 \mathrm{rd}$ piglet to be a decent choice. We thought it important to have a plan for which piglet to take, and to take it immediately after birth. Behaviour of the piglets that weren't sacrificed immediately after birth was recorded, and since there could be more than one sow farrowing at about the same time we needed to have 
some time available to call in more persons to be able to continue with recording of behavior while the chosen piglet was killed and dissected. Litter size varies considerably, but 3 piglets are almost always born. If the 3 rd piglet was stillborn, or a runt, the 4th (or 5th) piglet was taken. One day after birth the heaviest and the lightest piglet in these litters were killed and dissected in the same manner in order to investigate what influence piglet total lipid content would have on FA composition. In addition mortality rate is much higher in light than in heavy piglets. Thus it is of general interest to compare the extremes in birth weight.

Table 1a. Composition of the diets (as-fed) and analysed content of energy, protein and fat ( $\mathrm{g} / \mathrm{kg}$ feed) used in the trial.

\begin{tabular}{|c|c|c|c|c|}
\hline \multirow[b]{2}{*}{ Ingredient, \% } & \multicolumn{4}{|c|}{ Diet $^{a}$} \\
\hline & $\mathbf{L F}$ & HFS & HFO & HFL \\
\hline Barley & 14.1 & 46.0 & 1.74 & - \\
\hline Wheat & 42.3 & 19.2 & 33.5 & 33.8 \\
\hline Oats & 20.0 & 5.0 & - & 20.0 \\
\hline High fat oats & - & - & 40.0 & 20.0 \\
\hline Soya bean meal & 10.0 & 12.0 & 10.1 & 10.5 \\
\hline Wheat middlings & 5.0 & 5.0 & 5.0 & 5.0 \\
\hline Wheat bran & 5.0 & 5.0 & 5.0 & 5.0 \\
\hline Vitamin \& mineral premix ${ }^{b}$ & 1.0 & 1.0 & 1.0 & 1.0 \\
\hline Fat (Akofeed Standard) ${ }^{c}$ & 0.19 & - & 0.94 & 0.85 \\
\hline Fat (Akofeed Cattle 45) ${ }^{d}$ & - & 3.65 & - & - \\
\hline Monocalcium phosphate & 1.03 & 1.51 & 1.05 & 1.32 \\
\hline Limestone & 0.95 & 1.02 & 1.19 & 1.00 \\
\hline Sodium chloride & 0.40 & 0.40 & 0.40 & 0.40 \\
\hline L-Lysine $\mathrm{HCl}$ & 0.08 & 0.07 & 0.04 & 0.05 \\
\hline DL-Methionine & 0.01 & 0.07 & 0.04 & 0.07 \\
\hline L-Threonine & 0.04 & 0.08 & 0.02 & 0.02 \\
\hline Linseed oil ${ }^{e}$ & & & & 1.00 \\
\hline
\end{tabular}

Calculated composition, \%

\begin{tabular}{lcccc}
\hline Dry matter & 88.6 & 88.4 & 89.6 & 89.4 \\
Crude protein & 15.3 & 15.0 & 15.4 & 15.4 \\
Lysine & 0.70 & 0.72 & 0.71 & 0.71 \\
Methionine + Cystine & 0.56 & 0.59 & 0.64 & 0.63 \\
Threonine & 0.52 & 0.60 & 0.53 & 0.52 \\
Crude fat & 3.0 & 6.0 & 6.0 & 6.0 \\
Crude fibre & 4.8 & 4.6 & 6.4 & 6.0 \\
Ca & 0.80 & 0.90 & 0.90 & 0.87 \\
$P$ & 0.65 & 0.75 & 0.65 & 0.71 \\
\hline Metabolizable energy, MJ & 12.3 & 12.8 & 12.6 & 12.6 \\
\hline
\end{tabular}

${ }^{\mathrm{a}} \mathrm{LF}=$ low fat, HFS = high fat saturated, HFO = high fat oats, HFL = high fat linseed oil. ${ }^{\mathrm{b}}$ Contributed per kilogram of complete feed; 10,000 IU vitamin A, 1,000 IU vitamin D3, $60 \mathrm{mg}$ vitamin $\mathrm{E}, 2 \mathrm{mg}$ vitamin $\mathrm{K} 3,2 \mathrm{mg}$ vitamin B1, $4 \mathrm{mg}$ vitamin B2, 3 mg vitamin B6, 0.02 $\mathrm{mg}$ vitamin B12, $0.25 \mathrm{mg}$ biotin, $1.5 \mathrm{mg}$ folic acid, $20 \mathrm{mg}$ niacin, $15 \mathrm{mg} d$-pantothenic acid, $0.30 \mathrm{mg} \mathrm{I}, 0.30 \mathrm{mg} \mathrm{Se}, 40 \mathrm{mg} \mathrm{Fe}, 0.01 \mathrm{mg}$ Co, $10 \mathrm{mg} \mathrm{Cu}, 0.41 \mathrm{mg} \mathrm{Mg}, 20 \mathrm{mg} \mathrm{Mn}, 70 \mathrm{mg} \mathrm{Zn}$. ${ }^{c}$ Source of unsaturated fatty acids. ${ }^{\mathrm{d}}$ Source of saturated/monounsaturated fatty acids. ${ }^{\mathrm{e}}$ Linseed oil was added as a topdress at feeding, and was not included in the analysed feed. 
Table 1b. Fat content and fatty acid composition (\% of total identified) of the four diets used in the trial.

\begin{tabular}{|c|c|c|c|c|}
\hline $\begin{array}{l}\text { Fat content/ } \\
\text { Fatty acid }\end{array}$ & $\begin{array}{c}\text { Low fat } \\
\text { (LF) }\end{array}$ & $\begin{array}{l}\text { High fat saturated } \\
\text { (HFS) }\end{array}$ & $\begin{array}{l}\text { High fat oats } \\
\text { (HFO) }\end{array}$ & $\begin{array}{l}\text { High fat linseed } \\
\text { (HFL) }\end{array}$ \\
\hline Fat content, $\%$ & 3.2 & 5.5 & 5.9 & $5.9(4.9)$ \\
\hline $12: 0$ & 0.22 & 1.88 & 0.26 & 0.44 \\
\hline 14:0 & 0.30 & 1.38 & 0.27 & 0.30 \\
\hline $16: 0$ & 17.1 & 34.5 & 14.7 & 13.0 \\
\hline $16: 1$ & 0.21 & 0.22 & 0.19 & 0.13 \\
\hline $18: 0$ & 2.44 & 4.69 & 3.42 & 2.56 \\
\hline $18: 1 n-9$ & 23.7 & 27.3 & 40.1 & 29.9 \\
\hline $18: 1 n-7$ & 1.17 & 0.81 & 1.57 & 0.82 \\
\hline $18: 2 n-6$ & 48.2 & 24.9 & 34.2 & 33.9 \\
\hline $18: 3 n-3$ & 4.37 & 2.34 & 3.13 & 17.4 \\
\hline $20: 0$ & 0.23 & 0.27 & 0.32 & 0.22 \\
\hline $20: 1 n-9$ & 0.74 & 0.34 & 0.76 & 0.73 \\
\hline $22: 0$ & 0.17 & 0.13 & 0.16 & 0.06 \\
\hline$S F A$ & 20.6 & 43.0 & 19.2 & 16.7 \\
\hline$M U F A$ & 26.0 & 28.7 & 42.7 & 31.9 \\
\hline$P U F A$ & 52.6 & 27.3 & 37.3 & 51.2 \\
\hline PUFA n-6 & 48.2 & 24.9 & 34.2 & 33.9 \\
\hline PUFA n-3 & 4.37 & 2.34 & 3.13 & 17.4 \\
\hline$n-6 / n-3$ & 11.0 & 10.7 & 10.9 & 1.95 \\
\hline
\end{tabular}

SFA = saturated fatty acids; MUFA = monounsaturated fatty acids; PUFA = polyunsaturated fatty acids

Table 2. Sows' mean parity, life weight and backfat after farrowing.

\begin{tabular}{lcccccc}
\hline & LF & HFS & HFO & HFL & SEM & P-value \\
\hline Mean parity & 4 & 4.2 & 4.2 & 3.4 & 0.63 & 0.38 \\
Live weight, $\mathrm{kg}$ & 260 & 259 & 254 & 244 & 11.4 & 0.4 \\
Backfat, $\mathrm{mm}$ & 20.1 & 20.7 & 18.2 & 20.5 & 1.48 & 0.56 \\
\hline
\end{tabular}

Whole brain was sampled from the newborn piglets only while livers were taken in newborns, and at one day of age from both piglet sizes. Samples from liver and brain were collected and stored in $-80^{\circ} \mathrm{C}$.

Piglets from 39 litters (10 from groups 1, 2 and 3 respectively and 9 litters from group 4) were included in the study of liver FA analyses. For brain FA analyses only 5 piglets from each treatment group were chosen randomly. Within 24 hours after completed farrowing, sows were weighed and back fat was measured ultrasonically (Krautkrämer $\mathrm{BmbH}$ and Co., Hürth, Germany), approximately eight $\mathrm{cm}$ from the midline on both sides, at the level of the last rib, and the mean was recorded. There were no gilts included, and mean parity of sows was 3.9 (range 2-8). Mean parity, sows life weight and backfat after farrowing are presented in Table 2. The experimental procedures were carried out under the Swedish Animal Welfare Act 1988:534 (Scientific Procedures section) and were approved by the Uppsala Ethics Board for Animal Experimentation (No. C 81/1).

\section{Lipid analysis}

Lipids in brain and liver were extracted according to (Hara and Radin 1978). In brief, liver and brain samples, 1.0-2.0 g, were homogenised. Liver tissue was homogenised in $15 \mathrm{ml}$ hexan:isopropanol (3:2) 
(HIP). After homogenisation, $10 \mathrm{ml}$ HIP was used for rinsing the vessel, aqueous $\mathrm{Na}_{2} \mathrm{SO}_{4}(6.67 \mathrm{~g} / \mathrm{l})$ was added, and the tubes were manually shaken vigorously. Brain samples were extracted similarly, using $18 \mathrm{ml}$ of the solvent, rinsing with $2 \times 2 \mathrm{ml}$ of HIP and addition of $\mathrm{Na}_{2} \mathrm{SO}_{4}$. After a short centrifugation the upper layer was removed and dried under nitrogen gas and the lipids were dissolved in $1 \mathrm{ml}$ chloroform and stored at $-20{ }^{\circ} \mathrm{C}$ until further analysis. Total brain and liver lipids were weighed on a microbalance (UMT2, Mettler Toledo, Switzerland), and total lipid content was determined. Liver total lipids were separated into polar lipid (PL) and neutral lipid (NL) fractions with a method by (Prieto et al. 1992). Methylation of the brain total lipids, PL and NL of the liver lipids was performed as described by (Appelqvist, 1968) in dry methanol. The diets were extracted according to (Folch et al. 1957) and methylation was performed with dry methanol and $\mathrm{BF}_{3}$ addition, as described by (Appelqvist 1968). The content of crude fat in feed samples was analyzed according to (Official Journal of the European Communities, 1984) using Tecator-equipment (hydrolyze unit 1047 and extraction by Soxtec HT6). Analytical thin-layer chromatography (TLC) was carried out to check the completeness of fatty acid methyl ester (FAME) preparation. The TLC was performed in the solvent system hexane:diethylether:acetic acid $\quad(85: 15: 1, \mathrm{v} / \mathrm{v} / \mathrm{v})$. The FAME were stored in hexane at $-80{ }^{\circ} \mathrm{C}$ until further analysis.

\section{Analysis of FAME by gas liquid chromatography (GC)}

A fused silica capillary column BPX 70 (SGE, Austin, Texas, USA), length $50 \mathrm{~m}$, i.d. $0.22 \mathrm{~mm}, 0.25 \mu \mathrm{m}$ film thickness, was used. The column was fitted in a Chrompack CP 9001 gas chromatograph (Chrompack, Middelburg, Netherlands) equipped with a flame ionization detector and split/splitless injector. The samples of FAME dissolved in hexane were injected using an auto sampler CP 9050, and a split mode with a split ratio of $25: 1$. For analysis the GC was programmed to start at a temperature of $158^{\circ} \mathrm{C}$ for $5 \mathrm{~min}$, increasing to $220^{\circ} \mathrm{C}$ at a rate of $2{ }^{\circ} \mathrm{C} \mathrm{min}^{-1}$ and kept at this temperature for additional $5 \mathrm{~min}$. Helium was used as the carrier gas at a pressure of $150 \mathrm{kPa}$ and nitrogen was used as make-

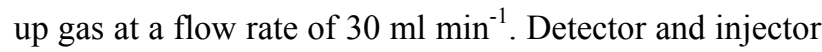
temperatures were at $250{ }^{\circ} \mathrm{C}$ and $230{ }^{\circ} \mathrm{C}$, respectively. The peak areas were identified and quantified by comparing their retention times and responses with those of a standard FAME mixture, GLC-68 A (Nu-Chek Prep,
Elysian, USA). The peak areas were integrated using a Maestro 2 version 2.4 (Chrompack, Middelburg, Netherlands) and presented as percentage of total lipid. All samples were analysed in duplicate and mean values are reported.

\section{Statistical analysis}

The results were evaluated by analysis of variance (general linear model procedure, GLM procedure, Minitab 6.0) with treatment, age and size as fixed factors and different groups were compared on the basis of least-square means. Tuckey's HSD (honestly significant difference) for multiple comparisons was calculated with an experimental vice error rate of $1 \%$ risk of false significance to evaluate the difference between the groups. The HSD value is used to show if the compared groups differ significantly from each other. Groups differ significantly from each other, when the difference between two groups is higher than the HSD value for each row in the tables.

\section{Results}

Diets

Dietary fat content was $3.2 \%$ by weight, in LF feed (control) compared to $5.5 \%$ and $5.9 \%$ in the high fat feeds. HFL had a fat content of $4.9 \%$ and $1 \%$ linseed oil was added manually as described above. HFS diet had the highest proportion of SFA (43\%) and the proportion of 16:0 was 2.5 fold compared to HFO and HFL. HFO diet had increased proportions of 18:1n-9 and 18:2n-6 compared to HFS and HFL and the ratio of n-6/n-3 was 11:1 in HFS and HFO compared to HFL which was 2:1. The overall highest proportion of 18:3n-3 was analyzed to be 7.4 and 5.5 fold higher in the linseed oil added feed (HFL) compared to diets HFS and HFO respectively (Table 1b).

\section{Piglets - Effect of sows' diet}

Treatment led to significant changes in FA composition of tissue lipids. The HFL-fed group, fed a high content of ALA, showed significant differences compared with the other groups (Tables 3, 4 and 5). The effect of the lower $n-6 / n-3$ ratio of the HFL feed is clearly reflected in the $n-6 / n-3$ ratio of total lipid of brain, being significantly lower in the linseed group (HFL-fed) (approximately 1.6:1) compared to 2:1 in the three other groups. There were only traces of ALA found in brain lipids, but the longer chain n-3 PUFA 22:5n-3 (DPA) and 
Table 3. Brain lipid composition of fatty acids (\% of total identified).

\begin{tabular}{|c|c|c|c|c|c|c|}
\hline $\begin{array}{l}\text { Diet } \\
\text { Fatty acid }\end{array}$ & $\begin{array}{c}\text { Low fat } \\
(\mathbf{L F}) \\
\mathbf{n}=5\end{array}$ & $\begin{array}{c}\text { High fat saturated } \\
\begin{array}{c}\text { (HFS) } \\
n=5\end{array}\end{array}$ & $\begin{array}{l}\text { High fat oats } \\
\begin{array}{c}\text { (HFO) } \\
n=5\end{array}\end{array}$ & $\begin{array}{l}\text { High fat linseed } \\
\begin{array}{c}(\text { HFL) } \\
\text { n=5 }\end{array}\end{array}$ & HSD & p-value \\
\hline 14:0 & 0.78 & 0.79 & 0.78 & 0.75 & 0.11 & 0.69 \\
\hline 16:0 & 21.7 & 21.9 & 21.7 & 21.4 & 0.86 & 0.52 \\
\hline $16: 1 \mathrm{tr}$ & 1.44 & 1.46 & 1.51 & 1.37 & 0.11 & 0.02 \\
\hline $16: 1 n-7$ & 1.09 & 1.14 & 1.11 & 1.10 & 0.09 & 0.50 \\
\hline 18:0 & 17.6 & 17.5 & 17.6 & 17.6 & 0.52 & 0.91 \\
\hline $18: 1 n-9$ & 13.3 & 13.2 & 13.1 & 13.3 & 0.95 & 0.87 \\
\hline $18: 1 n-7$ & 4.48 & 4.56 & 4.44 & 4.33 & 0.11 & 0.001 \\
\hline $18: 1 n-5$ & 0.33 & 0.31 & 0.31 & 0.34 & 0.11 & 0.75 \\
\hline $18: 2 n-6$ & 0.61 & 0.64 & 0.68 & 0.86 & 0.17 & 0.002 \\
\hline $18: 3 n-3$ & Trace & & & & & \\
\hline $20: 1 n-9$ & 0.41 & 0.41 & 0.40 & 0.44 & 0.06 & 0.96 \\
\hline $20: 3 n-6$ & 0.31 & 0.32 & 0.34 & 0.45 & 0.06 & 0.001 \\
\hline $20: 4 n-6$ & 11.0 & 11.0 & 11.2 & 10.7 & 0.46 & 0.11 \\
\hline $20: 5 n-3$ & Trace & & & & & \\
\hline $22: 4 n-6$ & 4.78 & 4.78 & 5.09 & 4.57 & 0.40 & 0.01 \\
\hline $22: 5 n-6$ & 2.65 & 2.70 & 2.65 & 1.40 & 0.52 & 0.001 \\
\hline $22: 5 n-3$ & 0.24 & 0.24 & 0.25 & 0.51 & 0.06 & 0.001 \\
\hline $22: 6 n-3$ & 9.32 & 9.32 & 9.14 & 10.7 & 0.77 & 0.001 \\
\hline$S F A$ & 40.1 & 40.1 & 40.0 & 39.8 & 0.92 & 0.69 \\
\hline$M U F A$ & 18.6 & 18.5 & 18.2 & 18.4 & 1.09 & 0.84 \\
\hline PUFA & 28.9 & 28.9 & 29.3 & 29.2 & 0.86 & 0.52 \\
\hline PUFA n-6 & 19.4 & 19.4 & 19.9 & 18.0 & 0.86 & 0.001 \\
\hline PUFA n-3 & 9.55 & 9.55 & 9.39 & 11.2 & 0.80 & 0.001 \\
\hline$n-6 / n-3$ & 2.03 & 2.04 & 2.12 & 1.61 & 0.23 & 0.001 \\
\hline
\end{tabular}

$\mathrm{n}=$ number; HSD = honestly significant difference; SFA = saturated fatty acids; MUFA = monounsaturated fatty acids; PUFA = polyunsaturated fatty acids

DHA were significantly increased in piglets from HFLfed sows compared to the other groups. Also LA and 20:3n-6 showed significantly higher values in the HFLfed group while 22:5n-6 decreased significantly in the HFL-fed group compared to the other three groups (Table 3). 22:4n-6 also showed decreased values in the HFL group, however the difference was only significant compared to the HFO group.

The levels of PUFA in the liver PL and NL in this study are shown in Table 4 and 5. Increased proportions of ALA and 20:5n-3 (EPA) were found in HFL fed group compared to the other groups. However increase of ALA was lower in PL than in NL. EPA content in HFL liver NL was increased in contrast to HFL liver PL.
The $n-6 / n-3$ ratio was significantly lower in the linseed group compared to the other groups for both liver PL and NL.

\section{Piglets - Effect of age/milk}

Liver PL FA were clearly altered after birth (Table 4). A clear increase in LA one day after birth compared to the newborns is seen in all groups, in addition there is an increase in 20:2n-6. This is balanced by a decrease in AA and DHA. In the linseed piglet group (HFL-fed) EPA was significantly decreased at day one after birth, compared to the newborn. Liver NL showed a general increase in PUFA with age, most dependent on the large increase of LA. In the linseed group in addition also ALA was increased in both PL and NL fraction at 
Table 4. Fatty acid composition (\% of total identified) of liver polar lipids.

\begin{tabular}{|c|c|c|c|c|c|c|c|c|c|c|c|c|c|}
\hline \multirow{2}{*}{$\begin{array}{l}\quad \text { Diet } \\
\text { Size of } \\
\text { piglet }\end{array}$} & \multicolumn{3}{|c|}{$\begin{array}{l}\text { Low fat } \\
\text { (LF) fed }\end{array}$} & \multicolumn{3}{|c|}{$\begin{array}{c}\text { High fat saturated } \\
\text { (HFS) fed }\end{array}$} & \multicolumn{3}{|c|}{$\begin{array}{l}\text { High fat oats } \\
\text { (HFO) fed }\end{array}$} & \multicolumn{3}{|c|}{$\begin{array}{l}\text { High fat linseed } \\
\text { (HFL) fed }\end{array}$} & \multirow{2}{*}{ HSD } \\
\hline & NB & $\mathbf{S}$ & $\mathbf{L}$ & NB & $\mathbf{S}$ & $\mathbf{L}$ & NB & $\mathbf{S}$ & $\mathbf{L}$ & NB & $\mathbf{S}$ & $\mathbf{L}$ & \\
\hline $14: 0$ & 0.41 & 0.27 & 0.25 & 0.55 & 0.31 & 0.20 & 0.67 & 0.42 & 0.30 & 0.52 & 0.23 & 0.20 & 0.25 \\
\hline $16: 0$ & 12.5 & 15.0 & 15.7 & 13.9 & 14.3 & 16.4 & 12.8 & 15.0 & 15.8 & 12.8 & 13.6 & 14.3 & 2.55 \\
\hline $16: 1 \mathrm{tr}$ & 0.62 & 0.64 & 0.58 & 0.69 & 0.70 & 0.53 & 0.70 & 0.71 & 0.66 & 0.53 & 0.59 & 0.53 & 0.34 \\
\hline $16: 1 n-7$ & 2.56 & 1.75 & 1.42 & 3.06 & 1.97 & 1.46 & 3.39 & 1.93 & 1.51 & 3.07 & 1.51 & 1.44 & 1.08 \\
\hline $17: 0$ & 0.45 & 0.46 & 0.29 & 0.61 & 0.33 & 0.14 & 0.48 & 0.25 & 0.40 & 0.46 & 0.42 & 0.29 & 0.49 \\
\hline 18:0 & 23.4 & 20.1 & 20.7 & 22.4 & 19.9 & 20.4 & 21.0 & 19.8 & 20.2 & 22.7 & 20.2 & 21.2 & 3.33 \\
\hline $18: 1 n-9$ & 10.4 & 13.3 & 11.7 & 10.9 & 13.0 & 11.9 & 10.2 & 13.1 & 12.6 & 9.95 & 13.9 & 13.1 & 3.46 \\
\hline $18: 1 n-7$ & 5.11 & 4.33 & 3.86 & 5.25 & 4.69 & 3.85 & 5.03 & 4.11 & 3.73 & 4.76 & 3.71 & 3.61 & 1.66 \\
\hline $18: 1 n-5$ & 0.14 & 0.11 & 0.17 & 0.10 & 0.15 & 0.15 & 0.15 & 0.14 & 0.17 & 0.21 & 0.17 & 0.20 & 0.20 \\
\hline $18: 2 n-6$ & 5.93 & 11.3 & 12.2 & 5.69 & 9.38 & 12.0 & 6.86 & 11.1 & 12.8 & 8.18 & 15.1 & 15.0 & 4.06 \\
\hline $18: 3 n-6$ & 0.17 & 0.21 & 0.17 & 0.16 & 0.20 & 0.17 & 0.21 & 0.15 & 0.17 & 0.13 & 0.12 & 0.16 & 0.16 \\
\hline $18: 3 n-3$ & 0.01 & 0.13 & 0.15 & 0.01 & 0.13 & 0.11 & 0.02 & 0.13 & 0.14 & 0.11 & 0.69 & 0.61 & 0.14 \\
\hline $20: 1 n-9$ & 0.18 & 0.25 & 0.20 & 0.20 & 0.30 & 0.23 & 0.20 & 0.25 & 0.25 & 0.19 & 0.24 & 0.22 & 0.12 \\
\hline $20: 2 n-6$ & 0.13 & 0.50 & 0.56 & 0.10 & 0.38 & 0.55 & 0.19 & 0.58 & 0.68 & 0.18 & 0.63 & 0.60 & 0.29 \\
\hline $20: 3 n-6$ & 0.83 & 0.86 & 0.91 & 0.79 & 0.89 & 0.90 & 0.81 & 0.66 & 0.94 & 1.25 & 1.19 & 1.27 & 0.60 \\
\hline $20: 4 n-6$ & 21.7 & 18.4 & 18.0 & 20.7 & 19.4 & 18.4 & 21.7 & 18.8 & 17.8 & 17.8 & 14.2 & 14.0 & 4.00 \\
\hline $20: 5 n-3$ & 0.32 & 0.17 & 0.15 & 0.34 & 0.21 & 0.16 & 0.18 & 0.19 & 0.13 & 1.60 & 0.92 & 0.86 & 0.29 \\
\hline $22: 4 n-6$ & 0.86 & 0.82 & 0.81 & 0.69 & 1.03 & 0.84 & 0.90 & 0.95 & 0.78 & 0.48 & 0.42 & 0.36 & 0.40 \\
\hline $22: 5 n-6$ & 2.38 & 1.38 & 1.42 & 2.39 & 1.95 & 1.22 & 2.85 & 1.66 & 1.44 & 1.09 & 0.48 & 0.46 & 0.97 \\
\hline $22: 5 n-3$ & 0.70 & 1.42 & 1.53 & 0.58 & 1.14 & 1.73 & 0.63 & 1.28 & 1.25 & 0.86 & 1.92 & 1.87 & 0.73 \\
\hline $22: 6 n-3$ & 6.13 & 4.55 & 5.31 & 6.14 & 4.72 & 4.68 & 5.78 & 4.20 & 4.49 & 8.31 & 5.53 & 5.80 & 1.67 \\
\hline$S F A$ & 36.8 & 35.8 & 36.9 & 37.5 & 34.9 & 37.1 & 35.0 & 35.5 & 36.8 & 36.5 & 34.4 & 35.9 & 4.23 \\
\hline MUFA & 18.4 & 19.7 & 17.3 & 19.5 & 20.1 & 17.6 & 19.0 & 19.5 & 18.2 & 18.2 & 19.5 & 18.5 & 4.44 \\
\hline PUFA & 39.2 & 39.8 & 41.5 & 37.6 & 39.5 & 41.0 & 40.1 & 39.8 & 40.7 & 40.0 & 41.7 & 41.5 & 3.83 \\
\hline PUFA n-6 & 32.0 & 33.4 & 34.1 & 30.5 & 33.2 & 34.2 & 33.5 & 33.9 & 34.5 & 29.2 & 32.2 & 31.9 & 3.49 \\
\hline PUFA n-3 & 7.20 & 6.39 & 7.31 & 7.12 & 6.31 & 6.83 & 6.65 & 5.94 & 6.17 & 10.9 & 9.5 & 9.56 & 1.78 \\
\hline$n-6 / n-3$ & 4.56 & 5.34 & 4.70 & 4.36 & 5.31 & 5.02 & 5.13 & 5.76 & 5.62 & 2.68 & 3.41 & 3.34 & 1.42 \\
\hline
\end{tabular}

$\mathrm{NB}=$ newborn; $\mathrm{S}=$ small at day $1 ; \mathrm{L}=$ large at day $1 ; \mathrm{HSD}=$ honestly significant difference; SFA = saturated fatty acids; MUFA = monounsaturated fatty acids; PUFA = polyunsaturated fatty acids

day after birth. This increase seems to be compensated by a decrease in the MUFA n-7 as both 18:1n-7 and 16:1n-7 were decreased significantly at day after birth compared to the newborn piglets.

The $n-6 / n-3$ ratio in the polar lipids of liver was increased at day one after birth in all groups except LFfed group. However this difference was not significant. In the NL fraction the $n-6 / n-3$ ratio was only slightly increased in the LF- and HFS-fed groups.

There was no significant difference in either PL or NL liver lipids between small and large piglets from the same treatment group (Tables 4 and 5). In general liver NL and PL fraction were affected in a similar way by diet.

\section{Discussion}

In earlier investigations it has been shown that FA composition of the diet influences FA composition in different tissues of pigs, piglets and milk (Amusquivar et al. 2008, Högberg et al. 2002, Högberg et al. 2001, Lauridsen and Jensen 2007, Nilzen et al. 2001, Panella- 
Table 5. Fatty acid composition (\% of total identified) of liver neutral lipids.

\begin{tabular}{|c|c|c|c|c|c|c|c|c|c|c|c|c|c|}
\hline \multirow{2}{*}{$\begin{array}{r}\text { Diet } \\
\text { Size of piglet }\end{array}$} & \multicolumn{3}{|c|}{ Low fat (LF) fed } & \multicolumn{3}{|c|}{$\begin{array}{l}\text { High fat saturated } \\
\text { (HFS) fed }\end{array}$} & \multicolumn{3}{|c|}{$\begin{array}{l}\text { High fat oats } \\
\text { (HFO) fed }\end{array}$} & \multicolumn{3}{|c|}{$\begin{array}{l}\text { High fat linseed } \\
\text { (HFL) fed }\end{array}$} & \multirow[t]{2}{*}{ HSD } \\
\hline & NB & $\mathbf{S}$ & $\mathbf{L}$ & NB & $\mathbf{S}$ & $\mathbf{L}$ & NB & $\mathbf{S}$ & $\mathbf{L}$ & NB & $\mathbf{S}$ & $\mathbf{L}$ & \\
\hline Fat content & 3.06 & 4.0 & 3.16 & 2.62 & 4.02 & 3.46 & 2.78 & 4.11 & 3.07 & 2.08 & 3.67 & 3.51 & 1.92 \\
\hline $14: 0$ & 2.55 & 1.88 & 1.90 & 3.12 & 2.06 & 1.61 & 3.70 & 2.36 & 2.06 & 3.22 & 1.58 & 1.64 & 1.24 \\
\hline 16:0 & 21.6 & 22.4 & 22.8 & 21.6 & 24.4 & 23.3 & 21.5 & 25.0 & 22.2 & 23.8 & 20.8 & 19.8 & 5.86 \\
\hline $16: 1 \mathrm{tr}$ & 3.22 & 2.74 & 2.85 & 3.28 & 2.86 & 2.50 & 3.40 & 3.12 & 2.96 & 2.83 & 2.21 & 2.52 & 1.14 \\
\hline $16: 1 n-7$ & 7.26 & 4.54 & 4.55 & 7.68 & 5.58 & 3.82 & 8.81 & 4.06 & 4.26 & 8.76 & 2.99 & 3.88 & 2.38 \\
\hline 17:0 & 0.47 & 0.23 & 0.31 & 0.35 & 0.42 & 0.19 & 0.36 & 0.48 & 0.22 & 0.60 & 0.12 & 0.11 & 0.58 \\
\hline $18: 0$ & 7.76 & 5.56 & 7.18 & 6.56 & 5.12 & 5.52 & 4.81 & 7.53 & 5.66 & 6.66 & 6.55 & 5.89 & 3.61 \\
\hline 18:1 tr & 0.38 & 0.24 & 0.27 & 0.26 & 0.29 & 0.32 & 0.24 & 0.15 & 0.30 & & 0.14 & 0.16 & 0.57 \\
\hline $18: 1 n-9$ & 33.9 & 31.3 & 31.0 & 33.6 & 31.0 & 32.6 & 30.2 & 28.4 & 31.4 & 33.1 & 32.4 & 32.1 & 7.25 \\
\hline $18: 1 n-7$ & 8.98 & 6.17 & 5.73 & 8.99 & 6.31 & 4.65 & 8.43 & 5.71 & 5.34 & 8.15 & 3.91 & 4.62 & 2.87 \\
\hline $18: 1 n-5$ & 0.21 & 0.37 & 0.15 & 0.25 & 0.30 & 0.23 & 0.24 & 0.27 & 0.28 & 0.27 & 0.15 & 0.16 & 0.70 \\
\hline $18: 2 \mathrm{tr}$ & 0.14 & 0.18 & 0.12 & 0.19 & 0.10 & 0.11 & 0.12 & 0.14 & 0.15 & 0.16 & 0.05 & 0.06 & 0.48 \\
\hline $18: 2 n-6$ & 3.05 & 13.3 & 13.6 & 3.17 & 11.1 & 14.1 & 5.66 & 10.9 & 14.7 & 3.7 & 16.6 & 15.6 & 7.79 \\
\hline $18: 3 n-6$ & 0.50 & 0.60 & 0.56 & 0.31 & 0.55 & 0.42 & 0.53 & 0.41 & 0.52 & 0.26 & 0.22 & 0.58 & 0.51 \\
\hline $18: 3 n-3$ & 0.06 & 0.64 & 0.56 & 0.08 & 0.48 & 0.74 & 0.13 & 0.46 & 0.60 & 0.30 & 2.68 & 2.74 & 0.65 \\
\hline $20: 1 n-9$ & 0.64 & 0.80 & 0.66 & 0.85 & 0.77 & 0.68 & 0.69 & 1.02 & 0.81 & 0.73 & 0.74 & 0.74 & 0.44 \\
\hline $20: 2 n-6$ & 0.29 & 0.47 & 0.40 & 0.11 & 0.40 & 0.48 & 0.21 & 0.44 & 0.56 & 0.13 & 0.53 & 0.50 & 0.38 \\
\hline $20: 3 n-6$ & 0.12 & 0.43 & 0.40 & 0.14 & 0.31 & 0.44 & 0.28 & 0.30 & 0.47 & 0.16 & 0.47 & 0.54 & 0.23 \\
\hline $20: 4 n-6$ & 1.60 & 0.89 & 1.82 & 1.06 & 1.71 & 2.11 & 1.26 & 1.97 & 1.72 & 0.64 & 1.34 & 1.33 & 2.06 \\
\hline $20: 5 n-3$ & 0.03 & 0.10 & 0.07 & 0.04 & 0.07 & 0.07 & 0.04 & 0.06 & 0.05 & 0.10 & 0.38 & 0.39 & 0.14 \\
\hline $22: 4 n-6$ & 0.27 & 0.34 & 0.24 & 0.26 & 0.38 & 0.38 & 0.42 & 0.49 & 0.29 & 0.10 & 0.16 & 0.18 & 0.44 \\
\hline $22: 5 n-6$ & 0.30 & 0.22 & 0.19 & 0.54 & 0.28 & 0.21 & 0.71 & 0.42 & 0.22 & 0.19 & 0.07 & 0.12 & 0.44 \\
\hline $22: 5 n-3$ & 0.13 & 0.33 & 0.24 & 0.12 & 0.23 & 0.36 & 0.16 & 0.26 & 0.17 & 0.17 & 0.57 & 0.61 & 0.30 \\
\hline $22: 6 n-3$ & 0.27 & 0.28 & 0.28 & 0.38 & 0.27 & 0.30 & 0.38 & 0.37 & 0.25 & 0.55 & 0.46 & 0.62 & 0.37 \\
\hline$S F A$ & 32.2 & 30.05 & 32.2 & 31.6 & 32.1 & 30.6 & 30.2 & 35.4 & 30.2 & 34.3 & 29.1 & 27.4 & 8.83 \\
\hline$M U F A$ & 51.4 & 43.30 & 42.2 & 51.6 & 44.2 & 42.0 & 48.6 & 39.9 & 42.3 & 51.2 & 40.4 & 41.8 & 9.16 \\
\hline$P U F A$ & 6.63 & 18.67 & 17.5 & 6.22 & 15.8 & 19.7 & 9.82 & 16.1 & 19.7 & 6.38 & 23.9 & 23.6 & 10.8 \\
\hline PUFA n-6 & 6.13 & 17.22 & 16.3 & 5.59 & 14.7 & 18.2 & 9.08 & 14.9 & 18.5 & 5.22 & 19.4 & 18.9 & 9.90 \\
\hline PUFA n-3 & 0.49 & 1.45 & 1.23 & 0.63 & 1.10 & 1.58 & 0.73 & 1.18 & 1.17 & 1.16 & 4.42 & 4.69 & 1.11 \\
\hline$n-6 / n-3$ & 12.6 & 13.9 & 14.6 & 9.19 & 13.6 & 12.3 & 15.4 & 11.9 & 16.0 & 4.48 & 4.40 & 4.01 & 8.17 \\
\hline
\end{tabular}

Abbreviations: see Table 4

Riera et al. 2007, Peinado et al. 2009, Pietras and Barowicz 2002) and it is known that it is in general rather easy to change muscle FA composition in pigs, being monogastric animals, compared to ruminants (Rule et al. 1995).

In the present study FA composition of sows' feed was reflected in both piglet brain total lipids and in liver membrane (polar lipids, (PL)) and storage lipids (neutral lipids, (NL)) which is in line with results in total liver lipids by Lauridsen and Jensen (2007). However, while the increased proportion of ALA in feed HFL led to increased amounts of ALA in NL in liver from both newborn and one day old piglets, in PL ALA was only increased one day after birth but not in newborn piglets. This is partly in line with Farnworth and Kramer (1989) who did not find an effect of maternal diet FA composition on FA composition of the fetus internal organs. The stronger pronounced increase of ALA in the NL fraction might be due to that the PL fraction is more stable in its composition, due to its functional properties 
(Scollan et al. 2001). In addition LA is preferably stored in the PL fraction, while ALA is stored more evenly in both fractions (Enser et al. 2000).

Beside the increased proportion of ALA in liver and brain, also an increase of the LC n-3 can be observed in the HFL-fed group, both in liver and brain in newborns and in liver at one day after birth, probably due to elongation and desaturation of ALA either by the sow or the piglet. These higher proportions of EPA in liver and DPA and DHA in brain of the piglets fed linseed, are in line with results from Innis et al. (1999) who reviewed that the essential LA and ALA are transported into the brain and used for synthesis towards longer PUFA. Bazinet et al. (2003) showed increased levels of both ALA and DHA in suckling piglets' liver and brain when sows had been fed a diet high in ALA (17.9\%), while Jimenez et al. (1997) found increased EPA and DHA but not DPA in liver when feeding piglets a supplemental proportion n-3 (1.3\% ALA compared to 0.7 in control diet). In our present study in liver tissue only EPA was significantly increased after feeding the HFL diet to the sows, suggesting an increased elongation and desaturation of ALA towards EPA with an higher intake.

However other results showed lack of elongation from ALA towards DPA and DHA in pigs (Jimenez et al. 1997, Rooke et al. 2000, Vaclavkova and Beckova, 2007).

Nevertheless, our results in brain suggest that a certain level ALA might be necessary to trigger the biosynthesis of DPA and DHA and that in general ALA from postnatal diet is taken up by the piglets and metabolized. To verify the hypothesis that a certain level of ALA is needed to activate biosynthesis of the LC n-3 PUFA, the influence of different levels of ALA on the expression of enzymes responsible for the synthesis of DPA and DHA should be investigated in different tissues.

Our results also suggest that there are different mechanisms for the metabolism of different $\mathrm{FA}$ in different tissues, which is in line with other results (review by Innis et al. 1999). The significant increase in ALA one day after birth implies that ALA is preferably transported from the sows' diet via the milk to the piglets. The similar pattern in all groups, with a significant increase of ALA one day after birth suggests that this transport via the milk is stronger in the neonatal piglet than via placental transfer. However, since no milk was analysed in the present study this hypothesis needs to be confirmed by an additional study.

Jimenez et al. (1997) and Amusquivar et al.
(2008) showed that composition of the consumed milk influences FA statues of piglets in different tissues and plasma but not or only minor in brain. Amusquivar et al. (2008) fed one emulsion rich in DPA and DHA and found significant increased proportions of only DHA in brain FA composition compared to a milk replacement and two other emulsions but not to a third one which had low levels of DHA as well. In the present study however, we could see a small but significant increase of both DPA and DHA in brain lipids. This is probably due to the higher proportion of ALA in our feed compared to other studies (Amusquivar et al. 2008, Jimenez et al. 1997) as well as the lower $n-6 / n-3$ ratio in our feed compared to Jimenez et al. (1997). This strengthens also our hypothesis that a certain level of ALA is necessary to activate synthesis towards LC PUFA.

Another aspect might be that Jimenez et al. (1997) fed the diet directly to the piglets while in our study the piglets might have received an increased proportion of LC PUFA via the milk. Yet, it needs to be further explored if the observed increase of DPA and DHA in our study does have physiological effects.

We have not analyzed the milk, however, Pietras and Barowicz (2002) showed increased ALA and EPA in sows colostrum and milk after feeding linseed, while Bazinet et al. (2003) found increased ALA and DHA but not EPA in sows milk with feeding of increased ALA and Lauridsen and Jensen (2007) demonstrated a clear influence of sows diet FA composition on milk FA composition regarding LA, ALA, EPA, DPA and DHA measured at days 4,8 and 25 of lactation, using 5 different diets from day 108 of gestation. Diets were either rich in saturated fat, LA from sunflower, ALA from rapeseed or n-3 LC PUFA from fish oil (Lauridsen and Jensen 2007). Lauridsen and Jensen (2007) found an apparent reflection of the milks composition in piglets' adipose tissue and liver during suckling, analysed on days 4, 8 and 25. We therefore assume that sows feed FA composition was similarly reflected in the sows' milk in the present study.

In line with the hypothesis that ALA is preferably transported via milk, also EPA is increased in the HFL-fed group in liver one day after birth compared to the neonatal piglet, suggesting either that also EPA is transported via the milk or an increased synthesis from ALA in the liver of the piglet. In order to understand these mechanisms better, milk FA composition needs to be analysed and a trial with supplementation of ALA compared to ALA and EPA via the milk should be 
executed. In spite of this, DHA is increased in the HFLfed group compared to the other feeding treatments but stable/decreasing after birth. This signifies that the piglets are not able to synthesise DHA in sufficient amounts themselves and that this FA is rather transported via bloodstream to the neonatal piglet. These results are consistent with earlier results on piglets (Rooke et al. 2000).

As pigs have similar FA metabolism as humans and the piglet has previously been used as a model for human infants (Innis 2000), results from the present study can also give some information for infants FA needs.

\section{Conclusions}

Our results are in line with Lauridsen and Jensen (2007), showing the possibility to increase liver n-3 of piglets by adding ALA to sows feed. Parallel to Morris et al. (1999) increased proportions of DPA and DHA in brain indicate that including a certain proportion ALA in sows diet can influence brain LC PUFA composition of piglets after birth. Further our results show that the FA transport from sow to piglet differs for different FA. While ALA is transported preferably via milk, DHA probably is rather transported via bloodstream in the uterus. The difference in the $n-6 / n-3$ ratio in the sows' diet and the consequent difference in the different tissues of piglets as demonstrated in the present experiment indicates that a balance between the essential FA LA and ALA might be of importance for piglet survival. However, further investigations are needed, to be able to define recommendations of proportions and content of certain essential FA in sows feed and their physiological effects.

\section{Conflict of Interest}

There is no conflict of interest.

\section{Acknowledgements}

This study was part of the research theme "Animal welfare for quality in food production", financed by the Swedish University of Agricultural Sciences (SLU). Funding was also received from the Swedish Farmers' Foundation for Agricultural Research, and from the Food 21 research programme financed by the Swedish Foundation for Strategic Environmental Research (Mistra).

\section{References}

AMUSQUIVAR E, SANCHEZ M, HYDE MJ, LAWS J, CLARKE L, HERRERA E: Influence of fatty acid profile of total parenteral nutrition emulsions on the fatty acid composition of different tissues of piglets. Lipids 43: 713$722,2008$.

APPELQVIST L-Å: Rapid methods of lipid extraction and fatty acid methyl ester preparation for seed and leaf tissue with special remarks on preventing the accumulation of lipid contaminants. Royal Swedish Academy of Science (Kungliga Svenska Vetenskapsakademien), Stockholm 28: 551-570, 1968.

ARC (Agricultural Research Council): The Nutrient Requirements of Pigs. Commonwealth Agricultural Bureaux, Slough, 1981, p. 307.

BAZINET RP, MCMILLAN EG, CUNNANE SC: Dietary alpha-linolenic acid increases the n-3 PUFA content of sow's milk and the tissues of the suckling piglet. Lipids 38: 1045-1049, 2003.

BLANARU JL, KOHUT JR, FITZPATRICK-WONG SC, WEILER HA: Dose response of bone mass to dietary arachidonic acid in piglets fed cow milk-based formula. Am J Clin Nutr 79: 139-147, 2004.

CLOSE WH, COLE DJA: Nutrition of Sows and Boars. Nottingham University Press, Nottingham, 2000, pp 333-372.

CUNNANE SC: Essential fatty acid/mineral interaction with reference to the pig. In: Fats in Animal Nutrition. WISEMAN J (ed), Butterworth, London, 1984, pp 167-183.

ENSER M, RICHARDSON RI, WOOD JD, GILL BP, SHEARD PR: Feeding linseed to increase the n-3 PUFA of pork: fatty acid composition of muscle, adipose tissue, liver and sausages. Meat Sci 55: 201-212, 2000.

FARNWORTH ER, KRAMER JKG: Fat metabolism in growing swine - a review. Can J Anim Sci 67: 301-318, 1987.

FARNWORTH ER, KRAMER JKG: Changes in the lipid composition of the internal organs of fetal pigs from sows fed different dietary fats. Can J Anim Sci 69: 441-448, 1989.

FOLCH J, LEES M, STANLEY SGH: A simple method for the isolation and purification of total lipides from animal tissues. J Biol Chem 226: 497-509, 1957. 
HARA A, RADIN NS: Lipid extraction of tissues with low toxicity solvent. Anal Biochem 90: 420-426, 1978.

HÖGBERG A, PICKOVA J, BABOL J, ANDERSSON K, DUTTA PC: Muscle lipids, vitamins E and A, and lipid oxidation as affected by diet and RN genotype in female and castrated male Hampshire crossbreed pigs. Meat Sci 60: 411-420, 2002.

HÖGBERG A, PICKOVA J, DUTTA PC, BABOL J, BYLUND AC: Effect of rearing system on muscle lipids of gilts and castrated male pigs. Meat Sci 58: 223-229, 2001.

INNIS SM: Essential fatty acids in growth and development. Prog Lipid Res 30: 39-103, 1991.

INNIS SM, SPRECHER H, HACHEY D, EDMOND J, ANDERSON RE: Neonatal polyunsaturated fatty acid metabolism. Lipids 34: 139-149, 1999.

INNIS SM: Essential fatty acids in infant nutrition: lessons and limitations from animal studies in relation to studies on infant fatty acid requirements. Am J Clin Nutr 71: 238S-244S, 2000.

JIMENEZ J, BOZA J, SUAREZ MD, GIL A: The effect of a formula supplemented with n-3 and n-6 long-chain polyunsaturated fatty acids on plasma phospholipid, liver microsomal, retinal, and brain fatty acid composition in neonatal piglets. $J$ Nutr Biochem 8: 217-223, 1997.

LAURIDSEN C, JENSEN SK: Lipid composition of lactational diets influences the fatty acid profile of the progeny before and after suckling. Animal 1: 952-962, 2007.

LAURITZEN L, HANSEN HS, JORGENSEN MH, MICHAELSEN KF: The essentiality of long chain n-3 fatty acids in relation to development and function of the brain and retina. Prog Lipid Res 40: 1-94, 2001.

LESKANICH CO: The comparative roles of polyunsaturated fatty acids in pig neonatal development. Br J Nutr 81: 87106, 1999.

MISSOTTEN JA, CLAEYS E, RAES K, DE SMET S: The influence of sow dietary PUFA source on the fatty acid profile of piglet tissues and blood and on piglet performance. Arch Tierz 51: 32, 2008.

MORRIS SA, SIMMER KN, VAN BARNEVELD R, GIBSON RA: Developmental sensitivity of the piglet brain to docosahexanoic acid. Pediatr Res 46: 401-405, 1999.

NCR (National Research Council): Nutrient Requirements of Swine. Washington, 1998, p. 189.

NILZEN V, BABOL J, DUTTA PC, LUNDEHEIM N, ENFALT A-C, LUNDSTROM K: Free range rearing of pigs with access to pasture grazing - effect on fatty acid composition and lipid oxidation products. Meat Sci 58: 267-275, 2001.

Official Journal of the European Communities: Determination of crude oils and fat. Method B., OJ. No 15: 29-30, 1984.

PANELLA-RIERA N, NEIL M, PICKOVA J: Evaluation of the influence of dietary fat content and fatty acid composition in four diets based on different fat sources on loins (M. longissimus dorsi) of newborn piglets. Arch Tierz-Arch Anim Breed 50: 72-78, 2007.

PASSINGHAM RE: Rates of brain development in mamals including man. Brain Behav Evol 26: 167-175, 1985.

PEINADO B, ALMELA L, DUCHI N, POTO A: Effects of two different diets on carcass and meat quality traits of Chato Murciano pigs. Arch Tierz-Arch Anim Breed 52: 150-160, 2009.

PIETRAS M, BAROWICZ T: Effect of dietary fat on the chemical composition and fatty acid profile of sows colostrum and milk. Med Weter 58: 134-137, 2002.

POWLES J, WISEMAN J, COLE DJA, HARDY B: Effect of chemical structure of fats upon their apparent digestible energy value when given to young pigs. Anim Prod 58: 411-417, 1994.

PRIETO JA, EBRI A, COLLAR C: Optimized separation of nonpolar and polar lipid classes from wheat-flour by solidphase extraction. J Am Oil Chem Soc 69: 387-391, 1992.

ROOKE JA, SHANKS M, EDWARDS SA: Effects of offering maize, linseed or tuna oils throughout pregnancy and lactation on sow and piglet tissue composition and piglet performance. Anim Sci 71: 289-299, 2000.

ROOKE JA, SINCLAIR AG, EDWARDS SA, CORDOBA R, PKIYACH S, PENNY PC, PENNY P, FINCH AM, HORGAN GW: The effect of feeding salmon oil throughout pregnancy on pre-weaning mortality of piglet. J Anim Sci 73: 489-500, 2001.

RULE DC, SMITH SB, ROMANS JR: Fatty acid composition of muscle and adipose tissue of meat animals. In: Biology of Fat in Meat Animals Current Advances. SMITH SB, SMITH DR (eds), 1st ed., American Society of Animal Science, Champaign, 1995, pp 144-165. 
SCOLLAN ND, DHANOA MS, CHOI NJ, MAENG WJ, ENSER M, WOOD JD: Biohydrogenation and digestion of long chain fatty acids in steers fed on different sources of lipid. J Agric Sci 136: 345-355, 2001.

SIMONSSON A: Nutrition recommendations and feeds for pigs. (in Swedish) Swedish University of Agricultural Sciences (SLU), Research Information Centre (Vol. 75), Uppsala, Sweden, 1994, p. 71.

SIMOPOULOS AP: The importance of the ratio of omega-6/omega-3 essential fatty acids. Biomed Pharmacother 56: 365-379, 2002.

VACLAVKOVA E, BECKOVA R: Effect of linseed in pig diet on meat quality and fatty acid content. Arch Tierz-Arch Anim Breed 50: 144-151, 2007. 